\title{
A PRIMER ON GOVERNANCE AND PERFORMANCE IN SMALL AND MEDIUM-SIZED ENTERPRISES ${ }^{1}$
}

\author{
Enrique Yacuzzi ${ }^{2}$
}

\begin{abstract}
This paper is a primer on corporate performance, corporate governance, and their interrelationships and measurement systems, with particular focus on Small and MediumSized Enterprises (SMEs). This is the first report of a larger on going research project.

In the domain of performance measurement the paper describes the trend from financial to non-financial measures, as well as a taxonomy of measures and the impact of the TQM movement on measurement practices. In the domain of governance, governance as a general concept is presented, followed by the more specific concept of corporate governance. Four theories of corporate governance are explained, along with literature findings on the relationship between corporate governance and corporate performance, with reference to both works on large firms and works on SMEs.
\end{abstract}

JEL: G30, G34, L25, M11.

Keywords: Corporate governance, corporate performance, measurement, small and medium-sized enterprises (SMEs)

\footnotetext{
${ }^{1}$ The views and opinions expressed in this publication are those of the author and are not necessarily those of the Universidad del CEMA.

${ }^{2}$ The author acknowledges University of CEMA Prof. Rodolfo Apreda's advice on the subject matter of this paper. The author is responsible for possible errors in this document.
} 


\section{INTRODUCTION}

Corporate governance concerns are old. Traces of the concept have been found in Shakespeare's The Merchant of Venice and in Adam Smith's The Wealth of Nations (Tricker (2005)). In recent decades, particularly since the 90's, the study of corporate governance has seen an unprecedented impulse: it is, indeed, a subject in the news. Scandals such as Enron's just gave further strength to an existing wave. ${ }^{3}$

This paper is a primer on corporate governance, corporate performance and their relationships. Two of its characteristics can be pointed out: its emphasis on the literature related to the measurement of corporate governance and corporate performance; and its application of concepts to Small and Medium-Sized Enterprises (SMEs). Methods to measure performance and governance are critical if we are to understand how the two concepts are related.

The paper aims at systematizing existing knowledge on corporate governance, including contingency success factors and performance measures. The research review looks primarily at the "big questions" in the field, although questions that deserve attention are presented, even if they are not "big". Until recently, most studies on corporate governance were related to large enterprises, particularly publicly-owned firms. In the past few years, however, the interest in corporate governance has spread to smaller organizations (Gabrielsson (ca. 2004), Gabrielsson (2003), Gabrielsson et al. (2004), Steger (2004)).

In spite of the large number of works published during the past decades, there are important areas of corporate governance still unexplored, such as the application of corporate governance in emergent economies. Governance issues in Latin American and Argentine firms have been studied (OECD (2003), Apreda (2001), and Agosin et al. (2003)), but there is much room for further contributions to this topic, for example, how financial and accounting performance and corporate measures can be expanded to include other important operational indicators. The technology to expand measurement already exists and there is ample opportunity to apply it to corporate governance in SMEs.

\footnotetext{
${ }^{3}$ For a detailed account of the Enron scandal from the perspective of corporate and global governance, see Apreda (2003 b).
} 
The rest of this paper is organized as follows. Section II is a preliminary, non systematic review on performance measurement. The trend from financial to non-financial measures is analyzed and a taxonomy of performance measures is presented, as well as the impact of the Total Quality Management (TQM) movement as a driver towards nonfinancial measures. Design and implementation of performance management systems is an important topic considered in this section. Finally, literature contributions to performance measurement at SMEs are briefly reviewed.

Section III is a short review of the literature on corporate governance. Governance as a general concept is presented, previous to the more specific concept of corporate governance. Four theories of corporate governance are explained: agency theory, stewardship theory, resource based theory, and stakeholder theory. Two important concepts close the section: corporate governance measurement and the application of corporate governance concepts to SMEs.

Section IV looks at the relationship between corporate governance and corporate performance. Reference is made to both works on large firms and works on SMEs. Section $\mathrm{V}$ is a short conclusion.

\section{PERFORMANCE MEASUREMENT, WITH PARTICULAR ATTENTION TO SMALL FIRMS}

\section{II.1 Performance evaluation: from financial to non-financial measures}

The word performance will be used with a wider meaning than productivity. While productivity relates an operations' output to the inputs required to produce it, performance - as we understand it-measures, in addition to productivity, many other concepts, such as the degree to which the firm meets customer expectations, the quality of working life, and product quality. If productivity relates to efficiency (how well resources are being used), performance relates to effectiveness (how well customers demands are being met). Performance measurement is "the process of quantifying action, where measurement is the process of quantification and action leads to performance." A performance measurement system, in addition, is a set of metrics used to quantify action (Neely et al. (1995)). 
Several reasons account for the popularity reached by performance measurement in recent years. These include: the changing nature of work; increasing competition; specific improvement initiatives; national and international quality awards; changing organizational roles; changing external demands; and the power of information technology (Neely (1999)).

Performance measures have traditionally been financial. However, more and more they are being considered insufficient by themselves ${ }^{4}$. One of the strongest concerns is that financial reporting often do no support investment in new technologies and markets, and this investment is required for enterprise advancement. Corporate balances measure historical issues, but they do not indicate potential yield of future technological and commercial opportunities. When financial measures were developed, corporate markets and products were much simpler than today's. Finally, financial measures tend to focus on the short term: the short length of employment of top executives and the practice to manipulate accounting figures do strengthen short term expectations.

In order to be useful, a performance measurement system has to be in line with corporate policies and must be applied consistently to realize strategy. It has also to be multidimensional, in order to capture the many aspects of an enterprise, its products and services. Approaches such as the balanced scorecard (Kaplan and Norton (1992)) and the multiple dimensions of quality (Garvin (1988)) were introduced to deal with the complexity of measuring efficiency and effectiveness.

\section{II.2 Perspectives on performance measures}

\section{II.2.1 A taxonomy of performance measures}

Given the great number of performance measures used through the years, some order in classification was called for. White (1996) proposes a taxonomy of strategy-related performance measures, reproduced in Table 1. The taxonomy deals with five classifications: competitive capability, data source, data type, reference, and process orientation.

\footnotetext{
${ }^{4}$ This paragraph is based on Eccles (2004).
} 


\begin{tabular}{|c|c|}
\hline Classification & Measure's focus \\
\hline \begin{tabular}{|l} 
Competitive capability \\
- $\quad$ Cost \\
- $\quad$ Quality \\
- $\quad$ Dexibility \\
- Speed reliability \\
Data source \\
- Internal \\
- External \\
Data type \\
- Subjective \\
- Objective \\
Reference \\
- Benchmark \\
- Self-referenced \\
Orientation \\
- Process input \\
- Process outcome
\end{tabular} & $\begin{array}{l}\text { Some aspect of cost } \\
\text { Some aspect of quality } \\
\text { Some aspect of flexibility } \\
\text { Delivery reliability } \\
\text { Speed } \\
\text { Data from sources within organization } \\
\text { Data from sources outside organization } \\
\text { Based on perception or opinion } \\
\text { Based on observable facts not involving opinion } \\
\text { Compares an organization with others } \\
\text { Does not involve any comparison with another } \\
\text { organization } \\
\text { Input to some process } \\
\text { Outcome of some process }\end{array}$ \\
\hline
\end{tabular}

Table 1. Classification of performance measures. Source: White (1996).

Table 1 can be used as a concept checklist to follow performance evolution through the history of an organization. A firm might detect that its evaluation of human resources performance is based on subjective data and that biased perceptions and opinions negatively affect company climate; the taxonomy then can remind the management that there are objective ways to conduct human resources evaluation. Likewise, a company could have been oriented to judge only the outcome of a production process but, faced with the need to improve product quality, the taxonomy suggests that controlling process inputs is equally possible and generally valuable.

\section{II.2.2 TQM as a driver to non-financial measures}

Total Quality Management (TQM) is a rich source of methods for performance measurement systems, which aim to evaluate the outcomes of overall corporate strategy. Thus, there must be harmony between strategy and the measurement system. TQM 
measures exhibit three important characteristics which help to put in parallel day-to-day actions and long-term goals: (1) They measure productivity and quality from a customer's viewpoint; (2) they are operations oriented, rather than accounting control oriented; and (3) they are disaggregated and function specific (Wruck and Jensen (1998)). The rest of this section shows how TQM tools, such as the national quality awards, standards such as ISO 9000, and benchmarking, set the trend for the introduction of a variety of measures of corporate performance. ${ }^{5}$

National Quality Awards. Performance measurement seeks to evaluate a large variety of items, a practice that strengthens the new trend towards non-financial measures. TQM was one of the main drivers to introduce non-financial measures in corporate evaluation. For example, Argentina's National Quality Award Basis, which are a model for evaluating organizational and management excellence in all kinds of organizations ${ }^{6}$, gives an important number of points to the analysis of non-financial results.

Table 2 compares the maximum allowable points for the components of the award model, for two versions of the award basis, corresponding to 1999 and $2004 .^{7}$ There are three main modules: leadership, management system, and results. The two versions differ slightly as performance measurement systems evolve. The maximum number of points to be assigned is 1000 .

The maximum assigned to leadership was reduced from 150 in 1999 to 110 in 2004. Other minor changes can be detected when comparing points for these two years, including the following: the maximum number of points for economic-financial results was reduced from 90 to 80 while the corresponding figure for operational results was increased from 50 to 70. These modifications suggest, in our opinion, a trend change that gives more importance to operations measures at the expense of financial measures.

Notice that customer satisfaction is among the indicators considered by the Award, as it is a fundamental measure of a firm's performance. It is not enough that a company gets

\footnotetext{
${ }^{5}$ The rest of this section is based on Yacuzzi (2005), Fundación Premio Nacional a la Calidad (1999), and Fundación Premio Nacional a la Calidad (2004).

${ }^{6}$ The Argentine award is very similar in general terms to other foreign awards, such as the Malcolm Balrige National Quality Award, USA.

${ }^{7}$ Sources: Fundación Premio Nacional a la Calidad (1999) and Fundación Premio Nacional a la Calidad (2004).
} 
good evaluation related to quality indicators if customer satisfaction and loyalty, market share evolution, and similar measures are not considered.

ISO 9000 standards. The trend change is visible through new standards, such as ISO 9000:2000, which incorporate the following aspects for evaluating corporate quality systems.

- Customer-focused organization

- Leadership

- Personnel participation

- Process-based approach

- Systems-based management

- Decision making based on facts

- Continuous improvement of processes

- Mutually beneficial relationship with suppliers.

A fundamental idea behind these systems is that "things that matter must be measured". If a company strategy highlights the importance of customer care, measures of how well the customer is being treated are key to the company. TQM people is fond of saying: "what is not measured cannot be improved, and even if it is improved, there is no way to know it”. Argentina's National Quality Award Basis indicate that, as part of each factor evaluation, the cycle of continuous improvement must be examined, inquiring in how processes are evaluated and improved.

In short, the quality movement has so far been the main driver of an expansion in the scope of performance measurement. Its compound metrics define measurement criteria in detail, and suggest that multiple measures, both financial and non-financial, are required. It is necessary to examine corporate strategy and inquire into what measures (financial and non-financial) must be controlled in order to achieve good financial results, sustainable in time. Families of measures have been proposed that include, for example, product quality, cash flow, process innovation, return on investment, and production process efficiency. 


\begin{tabular}{|c|c|c|}
\hline \multicolumn{3}{|c|}{ Table of maximum number of points } \\
\hline Component & $\begin{array}{c}1999 \\
\text { version }\end{array}$ & $\begin{array}{c}2004 \\
\text { version }\end{array}$ \\
\hline Leadership & 150 & 110 \\
\hline Strategic direction & 70 & 50 \\
\hline Compromise & 50 & 30 \\
\hline Social responsibility & 30 & 30 \\
\hline Management system & 400 & 440 \\
\hline Strategic planning & 100 & 80 \\
\hline Planning process/strategy development & 60 & 50 \\
\hline Strategies and plans/operational plans & 40 & 30 \\
\hline Focus on customers and markets & 100 & 100 \\
\hline Knowledge of customers and markets & 35 & 30 \\
\hline Management of customer relations & 25 & 25 \\
\hline Management of marketing channels & N/A & 10 \\
\hline Management of complaints and claims & 15 & 10 \\
\hline Determination of customer satisfaction and & & \\
\hline loyalty & 25 & 25 \\
\hline Process management & 100 & 100 \\
\hline Focus on process management & 30 & 20 \\
\hline $\begin{array}{l}\text { Design processes/design processes of products } \\
\text { and services }\end{array}$ & 25 & 20 \\
\hline Back-up, production and service processes & 20 & 50 \\
\hline Supplier-related processes & 10 & 10 \\
\hline Chain-distribution-related processes & 15 & N/A \\
\hline Human resources management/People management & & \\
\hline $\begin{array}{l}\text { Planning and execution/People and work } \\
\text { organization }\end{array}$ & 100 & 100 \\
\hline Education, training and development & 40 & 40 \\
\hline Personnel satisfaction/people satisfaction & 30 & 30 \\
\hline & 30 & 30 \\
\hline Results & 450 & 450 \\
\hline Customer management results & 120 & 100 \\
\hline Market share results & 50 & 50 \\
\hline Economic-financial results & 90 & 80 \\
\hline Operational results & 50 & 70 \\
\hline Supplier-related results & 20 & 20 \\
\hline Distribution-channel results & 20 & N/A \\
\hline Human resources/people management related & & \\
\hline results & 60 & 80 \\
\hline Social responsibility-related results & 40 & 50 \\
\hline
\end{tabular}

Table 2. National Quality Award, Argentina. Table with maximum number of points that can be assigned, classified in three components, for two years: 1999 and 2004 . Note: components to the left of the "y" correspond to 1999; components to the right, to 2004; 'N/A": Not applicable. 
Benchmarking. An important component of the quality movement is benchmarking, that is, "the comparison of processes and results that represent best practices and best performance for similar activities, be it in the same business sector to which the organization belongs to or in any other". ${ }^{8}$ Comparison of processes and results is made through both financial and non-financial measures, the latter being the most important for continuous improvement. Benchmarking impact is in large part psychological, since directors and employees become conscious of process possibilities and therefore change attitudes. In addition, benchmarking allows organizations to set objectives on the basis of concrete data, rather than on intuition; it facilitates implementation of process improvements, and it increases consciousness about the benefits of new technologies. ${ }^{9}$

Benchmarking assumes the following: (1) The firm knows its operational strengths and weaknesses; (2) the firm knows its competitors and industry leaders; and (3) the firm is decided to incorporate the best methods to gain superiority, by imitating and surpassing the strength of the industry leaders. ${ }^{10}$ These assumptions make mandatory the design and use of a solid performance measurement system.

\section{II.3 Performance measurement systems: design and implementation}

There are systematic ways to design a performance measurement system. Neely el al. (1997) provide one of such ways. Previously, Thor (1993 a) had offered 10 rules to build a measurement system and proposed a method to assemble a family of measures (Thor $(1993 \mathrm{~b}, 1993 \mathrm{c}))$. The method starts by considering what elements are important to measure, on the basis of the mission of each group in the organization, its clients (internal and external), its products and services; then a ranking is established in order to determine which the most important measures are. This determination can be performed by a committee, by the head of a department, or with the participation of all members of an organization, using adequate methodologies. The result will be an aggregated family of measures, integrating individual and group measures.

\footnotetext{
${ }^{8}$ Malcolm Baldrige Quality Award Basis, quoted in Fundación Premio Nacional a la Calidad (2004), p. 71, our translation.

${ }^{9}$ Rao et al. (1996), p. 562.

${ }^{10}$ Adapted from Camp, Robert C. (1993).
} 
Implementation of a complex measurement system is not immediate. In many organizations there are forces that oppose change and one of them is the shareholder's viewpoint. Eccles (2004) maintains that the main impediment for change is that investors are only concerned about financial data, something that we can verify in our professional practice.

Every company must do its homework in the arena of performance measurement. The design of non-financial performance measures, as well as its follow-up, is by itself hard work. Even harder is the interpretation of measures and its use in tandem with financial measures to fix strategies and manage key human resources activities, such as personnel promotion and incentive granting.

New technologies and database systems make the complementation of financial and non-financial measures possible. Elsewhere (Yacuzzi (2005)) we have proposed the following steps for system implementation. (1) Development of an information architecture; (2) development of an incentive system; and (3) implementation of a system to insure the functioning of information and incentive systems.

\section{II.4 Performance measurement at SMEs}

Benchmarking concepts have multiple applications in performance measurement. Dalrymple (2002), working from the Quality Management tradition, applies the International Business Profile Benchmarking to performance measurement of SMEs. The benchmark index is based on the following data: financial revenue and costs, financial capital, customer satisfaction, innovation, suppliers, people management, people satisfaction, business excellence (leadership, policy and strategy, people management, etc.). The author refers to the literature on performance measurement in large firms (Neely et al. (1995), Neely et al. (1997), White (1996), and Medori et al. (2000)) and, quoting Hudson et al. (2001), alerts about the barriers to strategic performance management systems in SMEs. The output of the comparisons provides tables with a variety of measures: profitability, financial management, productivity, investment, growth, customer service, innovation, supplier management, people management, and people satisfaction measures. On the basis of this output, operations can be reviewed and resources aligned in the intended strategic direction. 
With minor adaptations, methods developed for large firms can be used in SMEs as well. Thor's methods have been applied to SMEs in Argentina.

\section{CORPORATE GOVERNANCE AND ITS MEASUREMENT, WITH PARTICULAR ATTENTION TO SMALL FIRMS}

\section{III.1 Governance as a general concept}

Governance is a general concept. Corporate governance, our core interest in this paper, is thus a subset of the general concept; other subsets are public governance and global governance (Apreda (2003)). In general, it is understood by governance a 'field of learning and practice whose main tasks are:

- The search of principles, rules and good practices that allow organizations to be efficiently run within the current institutions, at a certain date;

- The design of mechanisms of representation, legitimate modes of wielding power, enforcement of rules and procedures, accountability, control, incentives and standards of performance to be applied to organizations;

- The efficacious pursuit of goals and missions that stem from the foundational charter and statutes of the organization.”(Apreda (2003 a), emphasis added.)

The terms in italics are particularly relevant for business organizations, both large companies and SMEs. No matter the nature of ownership or the kind of board of directors chosen by a firm, rules, incentives, standards, accountability, control, goals, mission, efficiency are key concepts that the study of governance brings to light. The trend towards a broader definition of governance is shared by authors such as Collin et al. (2004); they claim that corporate governance has to broaden its focus on the listed corporation, and reach other organizational forms, such as the associations, that they study.

\section{III.2 Corporate governance}

We focus now on the business corporation. A large number of definitions of corporate governance have been advanced through the years. The traditional definition is related to the protection of shareholder's interests (Tirole (2001)) and has roots in the issue of separation between management and control (Berle and Means (1932)). Much more recently, Monks and Minow (1995) (quoted by Apreda (2003 a)) maintain that corporate 
governance studies the "relationship among various participants in determining the direction and performance of corporations." For Kawakami et al. (1994), corporate governance is a generic term that describes the ways in which rights and responsibilities are shared among the various corporate participants, especially the management and the shareholders. It is a concept of higher order than management, as it is related to setting the firm' $\mathrm{s}$ objectives and checking that managers are behaving accordingly. These authors inquire into the meaning of governance and the reasons for its existence. They describe the main characteristics of corporations: (1) stockholders have limited responsibility; and (2) stockholders are not necessarily managers; and then explain that these traits, while producing great benefits, leave an open question, i.e., the impossibility of avoiding conflicting interests between owners and managers, among different owners, and the weak consciousness of "what is going on in the firm" on the part of the owners. Thus, some of the issues a governance system has to tackle are: Who and how appoints management? What responsibilities are taken upon by the people who appoint the management? Who and how checks the management? How to promote the group of candidates to management posts? How to dismiss management? (Kawakami et al. (1994).)

Executive compensation is an important subject for governance experts. HBR (2003), Abowd et al. (1999), Kaplan (1994), Bebchuk et al. (2003), Kane (2001), Fuller et al. (2002), Trébucq (2004) provide a good overview of a complex topic.

Apreda (2003 a) gives a working definition of governance that encompasses a number of perspectives. He defines corporate governance as the governance within corporations and nearly alike organizations (including state-owned firms) that brings to focus a number of subjects, displayed in Table 3.

\section{III.3 Theories On Corporate Governance}

Governance issues are receiving much attention around the world. Dore (2002), from an international perspective, and Apreda (2001), from the perspective of Argentina, are two examples of studies about a topic that grows in importance. Shleifer et al. (1997) offer a survey on corporate governance (today outdated but much quoted). Prowse (1995) presents different control mechanisms used by different firms in different countries. Clarke (2004) goes into detail in the analysis of theories of corporate governance. 


\section{Subjects of Corporate Governance}

- Ownership structure

- Company's founding Charter by -laws, statutes, and codes of good practice

- Board of Directors and Trustees. Allocation and control decision rights

- Managers' fiduci ary duties towards owners and their management decision rights

- Investors' property rights and protective covenants

- Conflicts of interests between managers, creditors, owners and other stakeholders

- Managers' performance and incentives

- Rent-seeking and soft-budget constraints

- Production and disclosure of information to markets, regulators and stakeholders

- Accountability to regulators, stakeholders and investors

- Private, public and global gatekeepers (reputational intermediaries)

- National and international institutional constraints (the Judiciary, traditions, regulations, and law enforcement).

Table 3. Main subjects of corporate governance. Source: Apreda (2003 a).

Demirag (1998 a) provides a general overview based on an international survey on corporate governance practices and management perceptions of short-term pressures from financial markets. Europe, North America, Australia, and Japan are included in the study. Demirag (1998 b) reviews the factors that are likely to cause short-term pressures and discusses bank-based and stock exchange-based financial systems and related governance systems, including the accountability of corporate management. Corporate governance systems are partially based on history (see, for example, Kawakami et al. (1994)) and culture. Kuada et al. (1998) offer culture as a framework to explain differences in governance systems around the world. Cultural development creates, according to these authors, a unique configuration of economic and management systems in which business practices evolve. Aoki (2003) analyzes why there is variety in corporate governance institutions on the basis of game theory and information theory. Several authors have approached the study of the Japanese system of corporate governance: Milhaupt et al. (2002), Latham (1999), Prowse (1992), Morck et al. (1999), Ahmadjian (2000), Doi (1998).

Such a rich scenario of viewpoints needs of some theories to systematize understanding. Different theories have been used to understand corporate governance. 
Sometimes, different recommendations and prescriptions emerge from them; at other times, they are complementary and coincide. In this section four theories of corporate governance are considered.

\section{III.3.1 Agency theory}

Agency theory studies situations in which a person works on behalf of other. An agency relationship arises between two or more parties when one of them, the agent, acts in representation of the other, the principal (Ross (1973)). For example, managers are agents of shareholders. When an agent gives priority to his own interests rather than those of his principal, agency relationships could become unclear; this is a frequent situation when the extent of both parties' rights and duties is not clearly established. In order to protect the principal's interests, agency theory proposes a series of measures, among which the separation of incumbency of roles of board chair and CEO is key (Donaldson et al. (1991)). Moe (1984) puts principal-agent models in the broader context of the economics of organization. Agency theory has important implications for the resolution of conflicts of interest among shareholders, managers and creditors (Jensen and Smith (1985)), as well as to generate predictions on dividend behavior (Dewenter et al. (1998)), and explain firm departures from the pecking order theories in emerging markets (Xuan et al. (1995)), among many other applications.

\section{III.3.2 Stewardship theory}

While agency theory is based upon un underlying model that assumes an individualistic actor that rationally maximizes his own personal gain, stewardship theory is built upon other views of man. Non-financial motivators do exist: people are motivated by the need to achieve, to be recognized by bosses and pairs, to exercise authority and responsibility, and to gain satisfaction through the performance of duties (Donaldson et al. (1991)).

Under stewardship theory, management does not behave opportunistically, but rather wants to do a good job; there is no need for extrinsic incentives. The organization

just has to create structures to facilitate clarification of role expectations and provide the necessary authority and empowerment to managers. Donaldson et al. (1991) and Vargas 
Sánchez (2001, 2004) present applications of stewardship theory. Smallman (2004) makes a defense of stewardship theory using concepts from various fields: engineering control theory, cybernetics and political science.

\section{III.3.3 Resource Based Theory (RBT)}

Resource Based Theory (RBT) is a dominant approach to business strategy, based on the concept of economic rent. For RBT the firm is a collection of capabilities. Unlike traditional strategy models, which focus on the company's external competitive environment and tend to ignore its internal workings and resources, RBT emphasizes the need for a fit between the external environment of a company and its internal capabilities.

RBT is grounded in the idea that a firm' $s$ internal environment, including its resources and capabilities, is more critical to the determination of strategic decision making than is the external environment, and a firm' s unique resources and capabilities provide the basis for a strategy that thoroughly exploits its core competencies relative to opportunities in the market. (Prahalad et al. (1990), Hamel et al. (1994)). RBT thus explains why SMEs are at a strategic disadvantage in governance issues and elsewhere for their lack of resources. In particular, SMEs suffer from the insufficiency of managerial know-how, which can be complemented by "outside" directors that provide advice to t he CEO and the managers when and where necessary (Gabrielsson and Huse (2004)).

\section{III.3.4 Stakeholder theory}

There are two traditional views to understand the objectives of a firm: The Shareholder Concept and the Stakeholder Concept. The former, rooted in the theory of accounting and finance, is associated with the maximization of shareholder wealth. The management should create as much wealth as possible for the shareholders. The latter, on the contrary, poses a broader range of objectives for a business—profit maximization being one of them-but it also measures the quality of corporate life, manager satisfaction, respect for society and the environment, and a variety of financial indicators.

Businesses are affected by their environment: customers, suppliers, government agencies, families of employees, special interest groups; in turn, the business decisions and actions are likely to affect one or more of these stakeholder groups. The managers of a firm 
should consider their responsibilities to groups other than the shareholders when making decisions. Stakeholder theory suggests that companies can benefit significantly from cooperating with a wide range of stakeholder groups, understanding their needs and making decisions accordingly.

Commentators disagree on the strengths and weaknesses of stakeholder theory. For instance, while Allen et al. (2002) consider that stakeholder capitalism can be superior to shareholder capitalism when markets are not perfect and complete, Heath et al. (2004) provide criticism.

\section{III.4 Governance of SMEs}

Governance of SMEs has special characteristics and problems. SMEs can be characterized by the following traits: Lack of material, financial and human resources, which impinges upon their bargaining power with customers, suppliers and financial institutions; limited managerial resources, including the time that management can devote to non routine activities; less qualified personnel than in larger companies; lack of strategic vision and long-range planning horizons; old ways to organize work; lack of training policies; scant information on markets and technologies; lack of innovation capacity. In spite of the importance of governance to the development of a market economy and the promotion of growth, SMEs are likely in a disadvantageous situation to secure the resources required and develop a corporate governance structure.

Conceptual frameworks built for the understanding and improvement in governance of large, publicly-owned enterprises have to be adapted when applied to SMEs. There are clear differences between larger and smaller firms, for instance in the amount of resources at hand and in the relationship among owners and managers. A promising avenue directly relevant to the application of governance concepts to smaller firms is that proposed by Gabrielsson et al. (2003), who identify value-creating board tasks with the help of four theories: agency theory, stewardship theory, resource dependency theory and stakeholder theory. These theories provide complementary prescriptions on ways in which boards create value; such ways can be the exploitation of business opportunities and the mobilization of resources to pursue them. 
The study of boards, one of the central issues in corporate governance, occupy an important place in the study of governance of SMEs as well. Gabrielsson and Huse (2004) recommend that SMEs recruit "outside" directors for various reasons. On the basis of 53 studies of outside directors in SMEs, the authors show how agency theory, RBT and resource dependence theory help to understand the various roles of outside directors in different firms, including family firms and venture capital firms. Nonetheless, different theories provide different perspectives on the concept of outside director, and these differences must be considered when looking at the role of outside directors.

Contingency theory plays an important role in the study of management and governance. Huse (2004) presents a framework of corporate governance with a contingency approach. Among important contextual factors the author identifies the national and cultural setting and the size of the firms. The frameworks also suggests the inclusion of considerations about actual board behavior. His ideas were presented in an expert meeting where one of the questions raised was "what can be learned from advanced market economies that is applicable to SMEs in transition economies?" The author provides some recommendations, including: the need to consider the actors involved en the design of a governance system, as well as the context for which the system is designed; the need to study board working style and characteristics of board members in the design of a governance system; and the need to promote through public education an understanding of good governance principles for SMEs.

One important contingency factor is the country in which a firm operates. Steger (2004) discusses corporate governance of German SMEs and reports that in Germany "aversion to the topic is widespread" among key actors such as SME executives, financial institutions and industry associations; this is true even for academics, who prefer to study large joint-stock companies. Nonetheless, the author recognizes that this aversion is "somewhat bizarre", particularly when the situation of other advanc ed countries is considered. German SMEs play a key role in the German economy: they are equivalent to $84 \%$ of all industrial firms, generate $41 \%$ of employment and receive $32 \%$ of investment. A high concentration of ownership and reluctance to attract external capital, including venture capital, is observed. The "aversion" factor includes aversion to "any controlling body inside the firm"; reluctant transparency; and the myth of the "good entrepreneur" who 
does not need bureaucratic regulation predominates. Steger (2004) anticipates some risks due to this situation in German SMEs: increases in financial difficulties, worsening of the climate between SMEs and financial institutions, decrease of public confidence, increase of problems with top-management succession and increase of economic criminality in the SME sector. On the basis of his study, the author recommends three things: a consensus about the necessity of a broad debate on corporate governance in SMEs among key actors; a wider discussion among academics; the creation of a corporate code for SMEs. This code should be practical, flexible, easy to understand, and should include among its principles: the transparency of management, a supervisory or advisory board with external members, a planning and risk management system (including internal reporting and cost accounting), a top management succession planning and human resource management.

\section{GOVERNANCE AND PERFORMANCE}

\section{IV.1 Relationship between governance and performance in large firms}

Empirical findings about the relationship between governance and performance in large firms are inconsistent among themselves. In this section we review some of the studies from the past few years. De Jong et al. (2002) perform a literature review on the relationship between corporate governance mechanisms and company performance and conclude that previous studies suggest that this relation can be positive, negative or inexistent. As a consequence, they recommend an empirical approach to study how corporate governance characteristics affects corporate performance. ${ }^{11}$ In addition to the literature search, in their own work De Jong et al. (2002) find that the governance system has an important influence on performance. They conduct a study involving Belgium, the Netherlands and the United Kingdom, three countries with different governance systems. Governance characteristics that are common to all countries, as well as country-specific characteristics, are included. Among other findings, it is suggested that country-specific characteristics have an influence on performance.

\footnotetext{
${ }^{11}$ The works de Jong et al. (2002) survey are the following: Jensen and Mecking (1976), Fama and Jensen (1983), Morck et al. (1988 and 1989), Lehman and Weigand (2000), Demsetz and Lehn (1985), Burkart et al. (1997), Bolton and von Thadden (1998), Demsetz and Villalonga (2001), Bethel et al. (1998), Franks et al. (2001), McConnell and Servaes (1990), Loderer and Martin (1997), Cho (1998), Himmelberg et al. (1999), Denis and Denis (1995), Borokhovich et al. (1996), and Agrawal and Knoeber (1996).
} 
Other authors such as Core, Holthausen, and Larcker (1999) also report mixed evidence from various studies. Black et al (2003 a) study the factors that predict a firm's score on a corporate governance index developed by the authors in an earlier paper (Black et al. (2003 b)). The index is composed of several sub-indices: shareholder rights, board structure, board procedure, disclosure to investors, and ownership parity. The importance of regulatory factors, industry factors, and firm-specific factors is explored. Regulatory factors are very important, as well as industry factors. Firm-specific factors have a more limited effect on governance. The most important firm-specific factors are: firm size (larger firms have better governance), firm risk (riskier firms show better governance); and long-term profitability (more profitable firms exhibit the worse governance).

Still other authors find a more definite impact of corporate governance on performance results. Rahman et al. (2005) report, from a study on Malaysian corporations, that companies with CEO's role duality seem to perform worse than companies with separate roles, in terms of accounting measures. Kao et al. (2004) show that board characteristics can affect earnings management : the larger the board size, the higher the extent of earnings management.

Using the impact of over twenty provisions, depicted in Table 5, Gompers et al. (2003) construct a governance index that they use as a proxy for the level of shareholder rights at some 1500 firms during the 90's. Their general conclusion is that firms with stronger shareholder rights have higher firm value, more profits and better sales growth; in addition, these firms show lower capital expenditures and make fewer corporate acquisitions.

Füerst et al. (2004) study the relationship between governance characteristics, including ownership, and corporate operating performance and stock price. The authors conduct a statistical analysis using expected residual income (ERI) as a performance measure, in order to introduce the expected operating performance of the firm. They conclude that share ownership and corporate governance characteristics significantly affect operating performance and stock prices.

Drobetz, Gugler, and Hirschvogl (2004) find a non-linear relationship between ownership concentration and the quality of corporate governance as measured by the German corporate governance rating developed by Drobetz, Schillhofer and Zimmermann 
(2004). Dey (2004) performs a sophisticated factor analysis and shows that the association between some governance indicators such as those related to the board and investor's confidence in reported earnings figures is stronger for firms with high agency costs.

\begin{tabular}{|c|c|}
\hline \multicolumn{2}{|c|}{ Governance Provisions } \\
\hline $\begin{array}{c}\text { Delay } \\
\text { - } \text { Blank check } \\
\text { - Classified board } \\
\text { - Special meeting } \\
\text { - Written consent } \\
\text { Protection } \\
\text { - Compensation plans } \\
\text { - Contracts } \\
\text { - Golden parachutes } \\
\text { - Indemnification } \\
\text { - Liability } \\
\text { - Severance } \\
\text { Voting } \\
\text { - Bylaws } \\
\text { - Charter } \\
\text { - Cumulative voting } \\
\text { - Secret ballot }\end{array}$ & 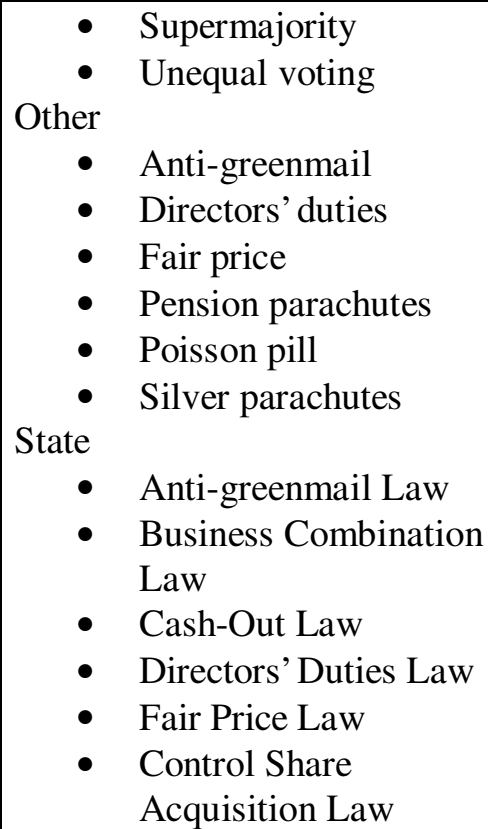 \\
\hline
\end{tabular}

Table 5. Governance provisions. See Gompers et al. (2003) for details.

Chiang (2005) presents an empirical study of the relationship between governance characteristics and operating performance in Taiwan's high-tech industry. The study shows that variables such as board size, board ownership, institution ownership, information transparency and board and management structure affect performance. In addition, information transparency is highlighted as one of the most important indicators of corporate performance.

A number of scholars have found no relationship between governance and performance measures. Larcker et al. (2004) provide results from a principal components analysis of data from over 2,100 firms. Their results suggest that the corporate governance indicators commonly used have poor explanatory power of managerial behavior and organizational performance. Hartzell et al. (2004) look at the role of corporate governance mechanisms in investment choices by analyzing data from real state investment trusts 
(REITs). They found, contrary to earlier studies, no strong relationship between corporate governance characteristics and Tobin's q. Nonetheless the authors found that the responsiveness of REIT's investment expenditures to their opportunities is related to their corporate governance structures.

Studies in public policy have also delved into the relationship between governance and performance. For example, Heinrich and Lynn (1999), compare statistical models to assess interactions among factors relevant to these issues. Kang et al. (1999) look into the relationship between "ownership organization" and firm performance with a "sociological tint".

\section{IV.2 Relationship between governance and performance at SMEs}

Small businesses have in general simple governance structures. Likewise, their governance issues are much simpler than in large firms (IBRF (2002)). Small firms do not exhibit complex management systems; do not use advanced pay and reward arrangements; and lack the resources required to compete with larger firms. Nonetheless, small firms can be innovative. The board of directors and the management, sometimes lead by the founder entrepreneur, can affect firm performance. Many firms make use of family networks to enhance governance.

The role of founders in company life and performance has been studied. Harding and Cowling (2003) maintain that founders of a SME have a positive effect on productivity while in office. They write:

“.. the relative strength of entrepreneurs in their dual roles as outwardlooking opportunists and firm organizers are not so clearly biased in favor of the opportunistic role as many small business commentators would have us believe. Our results suggest that a transfer of ownership and control away from the founding entrepreneur has the effect of reducing productivity, holding all else constant."

These authors also found that closely held ownership is not a barrier to productivity, and that as the number of directors increases, so does productivity. Likewise, non-executive directors on the board contribute to increased productivity. There is some evidence that human capital is key to productivity in small firms. In particular, relationships between a 
board of directors, the management layer and workers play an important role in increasing productivity in small firms, a role more important than capital increases. Cowling (2003) reports positive and significant effects from the company founder, the board and the management.

There are contributions from different cultural and political settings. Liang and Li (1999), based on a sample 228 small private firms in Shanghai, China, study the relationship between board structure and firm performance. They find that the presence of outside directors is positively associated with higher return on investment, although most of the firms display a board dominated by people internal to the organization. In addition, duality of titles does not affect firm performance, while higher technology tends to enhance firm performance. On the other side of the Pacific Ocean, Chhaochharia et al. (2004) measured the effect of the Sarbanes-Oxley Act and new corporate governance listing standards adopted by the NYSE and Nasdaq, rules adopted following corporate scandals. Among other findings, the authors report that "small firms that need to make large $r$ governance changes have lower returns, suggesting that the costs of implementing the rules might be larger than their benefits in small firms."

To conclude this preliminary review, we mention two studies. Bellalah (2004) reports a study of more than 60 French firms. Value creation in small firms, the study concludes, is explained by the same factors than large firms. Finally, Zafft (2002) highlights three challenges family-owned firms must cope with: growth, diversification and succession; the three challenges become harder when governance is poor, and better governance helps to improve the corporate functions and family welfare.

\section{CONCLUSIONS}

This primer reports on corporate governance, corporate performance, and their mutual relationships and measurement systems. Emphasis is placed on the application of these issues to the study of SMEs, with the aim of filling a gap in the literature and research activities. Several important topics converge in our endeavors, including the search for non-

financial performance measures as a complement to traditional financial measures and the application of corporate governance concepts to SMEs. Key to the improvement of SME management and strategy is the design of a performance management systems that allows 
the board of directors the implementation and monitoring of sound governance systems.

This document is a first step in that direction.

\section{REFERENCES}

1. Abowd, John M. and David S. Kaplan (1999). 'Executive Compensation: Six Questions That Need Answering", Journal of Eco nomic Perspectives, Vol. 13, No. 4, Fall, pp 145-168.

2. Agosin, Manuel R. and Ernesto Pastén H. (2003). 'Corporate Governance in Chile", Central Bank of Chile, Working Papers, No. 209, May.

3. Agrawal, A. and C. Knoeber (1996). 'Firm performance and mechanisms to control agency problems between managers and shareholders", Journal of Financial and Quantitative Analysis, Vol. 31, 377-397.

4. Ahmadjian, Christina L. (2000). 'Changing Japanese Corporate Governance', The Japanese Economy, vol. 28, no. 6, Chapter 9, November-December, pp. 59-84.

5. Allen, Franklin, and Douglas Gale (2002). "A Comparative Theory of Corporate Governance", in Social Science Research Network, http://papers.ssrn.com/ sol3/papers.cfm?abstract_id=442841.

6. Aoki, Masahiko (2003). 'Institutional Complementarities between Organizational Architecture and Corporate Governance", RIETI Conference on Corporate Governance, January 8-9.

7. Apreda, Rodolfo (2001). 'Corporate Governance in Argentina: the outcome of economic freedom (1991-2000), Corporate Governance, Vol. 9, Number 9, October, pp. 298-310.

8. Apreda, Rodolfo (2003 a). "The Semantics of Governance: The common thread running through corporate, public, and global governance", Working Paper Series, number 245, Universidad del CEMA, September.

9. Apreda, Rodolfo (2003 b). 'How Corporate Governance and Globalization Can Run Afoul of the Law and Good Practices in Business: The Enron's Disgraceful Affair", Working Paper Series, number 225, Universidad del CEMA, October.

10. Bebchuk, Lucian Arye and Jesse M. Fried (2003). 'Executive Compensation as an Agency Problem”, Working Paper 9813, NBER Working Paper Series, National Bureau of Economic Research, Cambridge, MA., July. Downloadable from http:// www.nber.org/papers/w9813.

11. Bellalah, Mondher (2004). 'On Investment Performance, Value Creation, Management and Corporate Governance: The French Case", Corporate Ownership and Control, Vol. 1, Issue 4, Summer, pp. 72-80.

12. Berle, A., Jr., and G. Means (1932). The modern corporation and private property. Commerce Clearing House, Chicago.

13. Bethel, J., J. Porter Liebeskind and T. Opler (1998). 'Block share purchases and corporate performance", Journal of Finance, Vol. 53, 605-634.

14. Black, Bernard S., Hasung Jang and Woochan Kim (2003 a). 'Predicting Firm's Corporate Governance Choices: Evidence from Korea", Stanford Law School, John M. Olin Program in Law and Economics, Working Paper No. 269, Social Science Research Network electronic library: http://papers.ssrn.com/ abstract $=428662$. 
15. Black, Bernard S., Hasung Jang and Woochan Kim (2003 b). 'Does Corporate Governance Affect Firms' Market Values? Evidence from Korea”, Working Paper available at Social Science Research Network electronic library: http:// ssrn.com/abstract $=311275$.

16. Bolton, P. and E. von Thadden (1998). 'Blocks, liquidity and corporate control", Journal of Finance, Vol. 53, 1-25.

17. Borokhovich, K., R. Parrino and T. Trapani (1996). 'Outside directors and CEO selection", Journal of Financial and Quantitative Analysis, Vol. 31, 337-355.

18. Burkart, M.m D. Gromb and F. Pannunzi (1997). 'Large shareholders, monitoring, and the value of the firm", Quart erly Journal of Economics, Vol. 112. 693-798.

19. Camp, Robert C. (1993). 'Benchmarking: The Search For Industry Best Practices That Lead To Superior Performance", in Christopher, William F. y Carl G. Thor (ed.), Productivity Press, Portland, OR.

20. Chhaochharia, Vidhi and Yaniv Grinstein (2004). 'Corporate Governance and Firm Value-The Impact of the 2002 Governance Rules", August (downloaded from http://ssrn.com./abstract=556990).

21. Chiang, Hsiang-tsai (2005) "An Empirical Study of Corporate Governance and Corporate Performance", Journal of American Academy of Business, Vol. 6, Issue 1, pp. 95, 7 p., March.

22. Cho, Myeong-Hyeon (1998). 'Ownership structure, investment and the corporate value: an empirical analysis", Journal of Financial Economics, Vol 47., 103-121.

23. Clarke, Thomas (2004). Theories of Corporate Governance. Routledge, London.

24. Collin, Sven-Olof and Elin Smith (2004). 'Strategy/structure and organizational development in riding schools: A model relating corporate governance and corporate entrepreneurship in the frame of property rights", Working Paper Series 2004:3, Kristianstad University College.

25. Core, J., R. Holthausen, and D. Larcker (1999). 'Corporate Governance, CEO Compensation, and Firm Performance", Journal of Financial Economics, 51, 371 -406.

26. Cowling, Marc (2003). 'Productivity and Corporate Governance in Smaller Firms", Small Business Economics, Vol. 20, Issue 4, pp. 335-44.

27. Dalrymple, John F. (2004). 'Performance Measurement for SME Growth: A Business Profile Benchmarking Approach", Second World Conference on POM and $15^{\text {th }}$ Annual POM Conference, Cancun, Mexico, April 30 - May 3.

28. De Jong, Abe, Carles Gispert, Rezaul Kabir and Luc Renneboog (2002). 'International Corporate Governance and Firm Performance: An Empirical Analysis",

Second Draft, May. Downloadable from selene.uab.es/dep-economia-empresa/ BECGroup/WP_Int_Corp_Gov.pdf.

29. Demirag, Istemi S. (1998 a) (Ed.). Corporate Governance, Accountability, and Pressures to Perform: An International Study". JAI Press, Inc., Stamford, Connecticut and London, England.

30. Demirag, Istemi S. (1998 b). 'Short termism, financial systems, and corporate governance: A theoretical framework", in Demirag (1998 a), pp. 7-24.

31. Demsetz, H. and B. Villalonga (2001). 'Ownership structure and corporate performance", Journal of Cor porate Finance, Vol. 7, 209-233.

32. Demsetz, H. and K. Lehn (1985). "The structure of corporate ownership: causes and consequences", Journal of Political Economy, Vol. 93, 1155-1177. 
33. Denis D. and D. Denis (1995). 'Performance changes following top management dismissals", Journal of Finance, Vol. 50, 1029-1057.

34. Dewenter, Kathryn L., and Vincent A. Warther (1998). 'Dividends, Asymmetric Information, and Agency Conflicts: Evidence from a Comparison of the Dividend Policies of Japanese and U.S. Firms", The Journal of Finance, Vol. LIII, No. 3, June.

35. Dey, Aiyesha (2004). 'Corporate governance and financial reporting credibility", December. (Downloadable from http://www.kellogg. northwestern.edu/faculty /dey/VersionInvestors 2004 12 27.pdf.)

36. Doi, Noriyuki (1998). 'Corporate Governance, Corporate Control, and R\&D in Japanese Manufacturing”, en Demirag (1998), pp. 333 -361.

37. Donaldson, Lex, and James H. Davis (1991). 'Stewardship Theory or Agency Theory: CEO Governance and Shareholder Returns", Australian Journal of Management, 16, 1, pp. 49-65.

38. Dore, Ron (2002). "The globalization of corporate governance", downloadable from www.ragm.com/hottopics/2002/RonDoreTheGlobalizationOfCorporateGovernance20 2.pdf

39. Drobetz, Wolfgang, Klaus Gugler, and Simone Hirschvogl (2004). 'The Determinants fo the German Governance Rating". (Downloadable from: www.wwz.unibas.ch/cofi/ publications/papers/2004/02-04.pdf)

40. Drobetz, Wolfgang, A. Schillhofer, and H. Zimmermann (2004). 'Corporate governance and expected stock returns: Evidence from Germany", European Financial Management 10 (2), 267-293.

41. Eccles, Robert (2004). 'Manifiesto sobre la medida del rendimiento", in Harvard Business Review (Ed.) (2004), Cómo medir el rendimiento de la empresa, Deusto. (Originalmente publicado en 1991.)

42. Fama, Eugene F. and Michael C. Jensen (1983). 'Separation of Ownership and Control", Journal of Law and Economics, vol. XXVI, June. Reproducido en Jensen, Michael C. (1998), Foundations of Organizational Strategy, Harvard University Press, Cambridge, MA.

43. Franks, J., C. Mayer and L. Rennenboog (2001). 'Who disciplines management in poorly performing companies?”, Journal of Financial Intermediation, Vol. 10, 209 248.

44. Füerst, Oren and Sok-Hyon Kang (2004). 'Corporate Governance, Expected Operating Performance, and Pricing”, Corporate Ownership \& Control, Vol. 1, Issue 2, Winter, pp. 13-30.

45. Fuller, Joseph, and Michael C. Jensen (2002). 'Just Say No to Wall Street: Courageous CEOs are putting a stop to the earnings game and we will all be better off for it.", Journal of Applied Corporate Finance, Vol. 14, No. 4 (Winter), pp. 41-46.

46. Fundación Premio Nacional a la Calidad, Ed. (1999). Bases del Premio Nacional a la Calidad: Criterios para una gestión de excelencia, 1999. Buenos Aires.

47. Fundación Premio Nacional a la Calidad, Ed. (2004). Bases del Premio Nacional a la Calidad: Modelo para una gestión empresarial de excelencia, 2004. Buenos Aires.

48. Gabrielsson, Jonas (ca. 2004). «Board Empowerment in Small Firms : Empirical Evidence from Sweden". Downloadable from: http://www.sses.com/ public/events/euram/complete_tracks/corporate_governance/gabrielsson.pdf

49. Gabrielsson, Jonas (2003). 'Boards and governance in SMEs: An inquiry into boards' contribution to firm performance", SIRE, Halmstad University, Sweden. 
50. Gabrielsson, Jonas and Morten Huse (2004). "Corporate 'Outside” Directors in SME Boards: A Call for Theoretical Reflections", paper presented at the Working Party on Industry and Enterprise Development, Committee for Trade, Industry and Enterprise Development, Economic Commission for Europe, Paper No. 18, April 1-2.

51. Gabrielsson, Jonas and Diamanto Politis (2003). 'Boards and governance in small firms: An integrated view on value-creating board tasks".

52. Garvin, David A. (1988). Managing quality, Free Press.

53. Gompers, Paul A., Joy L. Ishii, and Andrew Metrick (2003). 'Corporate Governance and Equity Prices", Quarterly Journal of Economics 118(1), Feb ruary, 107-155.

54. Hamel, Gary, and C.K. Prahalad (1994). Competing for the future. Harvard Business School Press, Boston, MA.

55. Harding, Rebecca and Marc Cowling (2003). 'Enterprise, corporate governance and productivity: A survey of unquoted companies", The W ork and Enterprise Panel of Inquire, The Work Foundation, Briefing paper No.2, June.

56. Hartzell, Jay C., Libo Sun, and Sheridan Titman (2004). "The effect of corporate governance on investment: Evidence from real estate investment trusts (REITs)", downloadable from http://cref.mccombs.utexas.edu /research/Hartzell.Sun.Titman.pdf

57. Harvard Business Review, Ed. (2003). 'What's wrong with executive compensation?", pp. 69-77. January.

58. Heath, Joseph, and Wayne Norman (2004). 'Stakeholder Theory, Corporate Governance and Public Management", Journal of Business Ethics 53, pp. 247-265.

59. Heinrich, Carolyn J. and Laurence E. Lynn, Jr. (1999). 'Means and Ends: A Comparative Study of Empirical Methods for Investigating Governance and Performance", Draft, prepared for the Fifth National Public Management Research Conference, George Bush School of Public Service, Texas A\&M University, December 3-4.

60. Himmelberg, C., R.G. Hubbard and D. Palia (1999). 'Understanding the determinants of managerial ownership and the link between ownership and performance", Journal of Financial Economics, Vol. 53, 353-384.

61. Hudson, M., A. Smart, and M. Bourne (2001). "Theory and practice in SME performance measurement systems", International Journal of Operations and Production Management, Vol. 21, No. 8, pp. 1096-1115.

62. Huse, Morten (2004). 'Corporate Governance in Advanced Market Economies: Understanding Important Contingencies", paper presented at the Working Party on Industry and Enterprise Development, Committee for Trade, Industry and Enterprise Development, Economic Commission for Europe, Paper No. 17, April 1-2.

63. Huse, Morten and Jonas Gabrielsson (2002). «The accumulation of knowledge of boards of directors-Contributions from 100 student reports", Paper presented at EURAM $2^{\text {nd }}$ Annual Conference, Stockholm, May 9-11.

64. IBRF (The International Bank for Reconstruction and Development/The World Bank) (2002). World Development Report 2002: Building Institutions for Markets, Oxford University Press, New York, NY.

65. Jensen M. and J. Meckling (1976). "Theory of the firm: managerial behavior, agency costs and ownership structure", Journal of Financial Economics, Vol. 4, 305-329.

66. Jensen, Michael C., and Clifford W. Smith, Jr. (1985). 'Stockholder, Manager, and Creditor Interests: Applications of Agency Theory", Recent Advances in Corporate 
Finance, E. Altman and M. Subrahmanyam, Ed., Dow-Jones Irwin, downloadable from http://hupress.harvard.edu/catalog/lENTHE.html.

67. Kane, Edward J. (2001). 'Using deferred compensation to strengthen the ethics of financial regulation", Working Paper 8399, NBER Working Paper Series, National Bureau of Economic Research, Cambridge, MA., July. Downloadable from http:// www.nber.org/papers/w8399.

68. Kang, David L. and Aage B. Sorensen (1999). 'Ownership Organization and Firm Performance", Annual Review of Sociology, Vol. 25, pp. 121-144.

69. Kao, Lanfeng, and Anlin Chen (2004). "The effects of board characteristics on earnings management", Corporate Ownership \& Control, Vol. 1, Issue 3, Spring, pp . 96-107.

70. Kaplan, R. S. And D. P. Norton (1992). "The balanced scorecard-measures that drive performance", Harvard Business Review, January-February, pp. 71-79.

71. Kaplan, Steven N. (1994). "Top Executive Rewards and Firm Performancee: A Comparison of Japan and the United States", Journal of Political Economy, vol. 102, No. 3, pp. 510-546.

72. Kawakami, Tetsurou, Ryuuichi Nagao, Hiroyuki Itami, Tadao Kagono, Tetsuji Okazaki (1994). Nihongata keiei no eichi (The Wisdom of Japanese Style Management), PHP Kenkyuusho, Tokyo.

73. Kuada, John and Hans Gullestrup (1998). "The cultural context of corporate governance, performance pressures, and accountability", in Demirag (1998 a), pp. 25 56.

74. Larcker, David F., Scott A. Richardson, and Irem Tuna (2004). 'Does Corporate Governance Really Matter?”, http://knowledge.wharton.upenn. edu/papers 1281.pdf.

75. Latham, Mark (1999). 'Corporate Governance in Japan: A Future Scenario”, Japanese translation to appear in Security Analysts Journal [Shouken Anarisuto Jaanaru], January 2000. Downloadable from www.corpmon. com/CGJapan Future.htm.

76. Lehman, E. and J. Weigand (2000). 'Does the governed corporation perform better? Governance structures and corporate performance in Germany", European Finance Review, Vol. 4, 157-195.

77. Liang, Neng and Joanne Li (1999). 'Board Structure and Firm Performance: New Evidence from China's Private Firms", Paper presented at the Academy of Management Annual Conference, Chicago, USA, August 7-10.

78. Loderer, Claudio and Kenneth J. Martin (1997). 'Executive Ownership and Performance: Tracking Faint Traces”, Journal of Financial Economics, Vol. 45, No. 2, August, pp. 223-256.

79. McConnell, J. and H. Servaes (1990). "Additional evidence on equity ownership and corporate value", Journal of Financial Economics, Vol. 27, 595-612.

80. Milhaupt, Curtis J., and Mark D. West (2002). 'Institutional Change and M\&A in Japan: Diversity Through Deals", downloadable from http://papers.ssrn. com/sol3/papers.cfm?abstract_id=290744

81. Moe, Terry M. (1984). "The New Economics of Organization," American Journal of Political Science, Vol. 28, November 1984, pp. 739-777.

82. Monks, Robert A. G. and Nell Minow (1995). Corporate Governance, Blackwell.

83. Morck, R., A. Shleifer and R. Vishny (1989). "Alternative mechanisms of corporate control", American Economic Review, Vol. 79, 842-852. 
84. Morck, R., A. Schleifer and R. Vishny (1988). 'Management ownership and mark et valuation: an empirical analysis", Journal of Financial Economics, Vol. 20, 293-315.

85. Morck, Randall and Masao Nakamura (1999). "Banks and Corporate Control in Japan”, The Journal of Finance, Vol. LIV, No. 1, February, pp. 319-339.

86. Neely, Andy, M. Gregory and K. Platts (1995). 'Performance measurement systems design: a literature review and research agenda", International Journal of Operations and Production Management, Vol. 15, No. 4, pp. 80-116.

87. Neely, Andy, H. Richards, J. Mills, and K. Platts (1997). 'Designing performance measures: a structured approach", International Journal of Operations and Production Management, Vol. 17, No. 11, pp. 1131-1152.

88. Neely, Andy (1999). "The performance management revolution: why now and what next?", International Journal of Operations and Production management, Vol. 19, No. 2, pp. 205-228.

89. OECD (2003). White Paper on Corporate Governance in Latin America. http://www.oecd.org/document/61/0,2340,en__ 2649_34691_18979325_1_1_1 - 1,00.html

90. Prahalad, C.K. and Hamel, G. (1990). "The core competence of the corporation", Harvard Business Review, May-June, pp. 79-81.

91. Prowse, Stephen D. (1992). 'The Structure of Corporate Ownership in Japan", The Journal of Finance, vol. XLVII, No. 3, July, pp. 1121-1140.

92. Prowse, Stephen (1995). "Corporate Governance in an International Perspective: A Survey of Corporate Control Mechanisms Among Large Firms in the U.S., U.K., Japan and Germany", Financial Markets, Institutions \& Instruments, Vol. 4, Number 1, New York University Salomon Center.

93. Rahman, Rashidah Abdul and Roszaini Mohd Haniffa (2005). "The effect of role duality on corporate performance in Malaysia", Corporate Ownership and Control, Vol. 2, Issue 2, Winter, pp. 40-47.

94. Rao, Ashok, Lawrence P. Carr, Ismael Dambolena, Robert J. Kopp, John Martin, Farshad Rafii, y Phyllis Fineman Schlesinger (1996). Total Quality Management: A Cross Functional Perspective. John Wiley and Sons, New York.

95. Ross, Stephen (1973). 'The Economic Theory of Agency: The Principal's Problem", Decision Making Under Uncertainty, Vol. 63, No. 2, May, pp. 134-139.

96. Shleifer, Andrei, and Robert W. Vishny (1997). "A Survey of Corporate Governance", The Journal of Finance, Vol. LII, No. 2, June, pp. 737-783.

97. Smallman, Clive (2004). 'Exploring theoretical paradigms in corpora te governance", International Journal of Business Governance and Ethics, Vol. 1, No. 1. pp. 78-94.

98. Steger, Thomas (2004). 'Corporate Governance of German SMEs - A review with special regards to the situation in East Germany.", Economic Commission For Europe Paper No. 6, Committee For Trade, Industry and Enterprise Development, Working Party on Industry and Enterprise Development, Expert meeting on Good Governance for SMEs, 1-2 April.

99. Shleifer, Andrei and Robert W. Vishny (1997). "A Survey of Corporate Gove rnance", The Journal of Finance, Vol. LII, No. 2, June, pp. 737-783.

100. Thor, Cark G. (1993 a). "Ten Rules for Building a Measurement System", in Christopher, William F. y Carl G. Thor (ed.), Productivity Press, Portland, OR. 
101. Thor, Cark G. (1993 b). "The Family of Measures Method for Improving Organizational Performance", in Christopher, William F. y Carl G. Thor (ed.), Productivity Press, Portland, OR.

102. Thor, Cark G. (1993 c). 'The Family of Measures Method: Application in Staff Departments", in Christopher, William F. y Carl G. Thor (ed.), Productivity Press, Portland, OR.

103. Tirole, Jean (2001). 'Corporate Governance”, Econometrica, Vol. 69, No. 1, January, pp. 1-35.

104. Trébucq, Stéphane (2004). "The Effects of ESOPs on Performance and Risk: Evidence from France", Corporate Ownership and Control, Vol. 1, Issue 4, Summer, pp. 81-93.

105. Tricker, Bob (2005). 'Corporate Governance - A Subject whose Time Has Come", Corporate Ownership \& Control, Vol. 2, Issue 2, Winter, pp. 11-27.

106. Vargas Sánchez, Alfonso (2001). La teoría de la agencia versus la teoría del servidor: una aplicación a las sociedades cooperativas agrarias de la provincia de Huelva. X International Conference of AEDEM. Reggio Calabria (Italia), 4-6 Septiembre 2001. En: Best Papers Proceedings, pp.1067-1076.

107. Vargas Sánchez, Alfonso (2004). 'Development of corporate governance systems: Agency theory versus stewardship theory in Welsh agrarian cooperative societies", Ponencia presentada en el $4^{\circ}$ Congreso Anual de EURAM (European Academy of Management). St. Andrews (Escocia), 5-8 Mayo.

108. White, G.P. (1996). "A survey and taxonomy of strategy related performance measures for manufacturing", International Journal of Operations and Production Management, Vol. 16, No. 3, pp. 42-61.

109. Wruck, Karen Hooper and Michael C. Jensen (1998). 'Science, Specific Knowledge, and Total Quality Management", in Jensen, Michael C. (1998), Foundations of Organizational Strategy, Harvard University Press, Cambridge, MA.

110. Xuan, Changneng and Richard D. MacMinn (1995). 'Pecking Order Theory in Emerging Market Economies-An Agency Theory Approach", Working Paper, University of Texas at Austin.

111. Yacuzzi, Enrique (2005). 'Un proceso de mejoramiento en Metalmecánica Porteña: Perspectivas desde la teoría de las organizaciones", unpublished report, Universid ad del CEMA, Tópicos de Organización Empresaria, Prof. Marcos Gallacher, 21 de febrero.

112. Zafft, Robert (2002). 'Large, Family -Run Firms: the OECD Experience', The Fourth Asian Roundtable on Corporate Governance, Shareholder Rights and the Equitable Treatment of Shareholders, OECD, Mumbai,India, 11-12 November. 